\title{
URGENSI KEARIFAN LOKAL MEMBENTUK KARAKTER BANGSA DALAM RANGKA PELAKSANAAN OTONOMI DAERAH
}

\author{
Oleh : \\ Lintje Anna Marpaung \\ Fakultas Hukum Universitas Bandar Lampung \\ Email : lintjeam@yahoo.com
}

\begin{abstract}
State of Indonesia is in the form of the republic, which consists of several islands. So called archipelago that has outstanding cultural richness and are not owned by another country, one of the Indonesian national pride by having a diversity of ethnic, tribal customs that have high values inherited by our ancestors to be conserved and have value quite high as a tool to build character as a nation and is the capital of local wisdom very proud of each region through provincial and district/city in the archipelago along still recognized and not contrary to the values of national wisdom that the values of pancasila .

Indigenous people ( MAHUdAT) and customs / traditional culture is still recognized its existence (living law) as mandated by Article 18 B in conjunction with Article 32The 1945 constitution jo permendagri No. 39 of 2007, for it needs to be implemented and used as the basic capital development in all fields in order of regional autonomy . Empowering Indigenous leader and kinship to participate in governance, which made the subsequent government policy areas outlined in the regulations. Thus is one way in the course of the Autonomous regional government through the area can be achieved good government.
\end{abstract}

Key words: Urgency, indigenous, people autonomous regional government.

\begin{abstract}
Abstrak
Negara Indonesia adalah Negara Kesatuan yang berbentuk Republik, yang terdiri dari beberapa pulau. Sehingga disebut dengan Nusantara yang memiliki kekayaan budaya yang luar biasa dan tidak dimiliki oleh negara lain, salah satu kebanggaan bangsa Indonesia dengan memiliki keanekaragaman etnis, suku budaya/ adat istiadat yang mempunyai nilai-nilai luhur yang diwariskan oleh nenek moyang untuk dilestarikan dan mempunyai nilai yang cukup tinggi sebagai alat untuk membangun karakter bangsa dan merupakan modal sebagai Kearifan lokal yang sangat dibanggakan oleh masing-masing daerah melalui Provinsi dan kabupaten/kota di seluruh Nusantara sepanjang masih diakui dan tidak bertentangan dengan nilai-nilai Kearifan nasional yaitu nilai-nilai Pancasila.

Masyarakat Hukum Adat ( MAHUDAT) beserta adat istiadat/budaya tradisionalnya hingga saat ini masih diakui keberadaannya (living law) sebagaimana yang diamanatkan oleh Pasal 18 B jo Pasal 32 UUD Negara Republik Indonesia Tahun 1945 jo Permendagri No 39 Tahun 2007, untuk itu perlu diimplementasikan dan digunakan sebagai modal dasar pembangunan di segala bidang dalam rangka penyelenggaraan otonomi daerah. Pemberdayaan Tokoh Adat dan Kekerabatannya untuk dapat berpartisipasi dalam penyelenggaraan pemerintahan, yang dibuat sebagai kebijakan Pemerintah Daerah selanjutnya dituangkan dalam Peraturan daerah. Sehingga dengan demikian merupakan salah satu cara dalam rangka penyelenggaraan Pemerintahan di Daerah melalui Otonomi daerah dapat tercapai Good government
\end{abstract}

Kata kunci: Urgensi, kearifan lokal, otonomi daerah.

\section{A. Pendahuluan}

Negara Indonesia adalah negara kesatuan yang berbentuk Republik, sebagaimana yang di atur dalam Pasal 1 ayat 1 . Negara Kesatuan Republik Indonesia dibagi atas daerah-daerah Provinsi dan dibagi atas kabupaten dan kota, yang terdiri dari beberapa pulau pulau, dan disebut dengan nusantara, saat ini terdiri dari 33 Provinsi, dan dihuni oleh beraneka ragam suku, adat istiadat/budaya serta agama. Pemeritah daerah provinsi, daerah kabupaten, daerah kota, mengurus sendiri urusan pemerintahannya, sebagaimana yang diamanatkan Pasal 18 UUD1945, dan seterusnya Negara mengakui dan menghormati satuan-satuan pemerintahan daerah yang bersifat khusus atau bersifat istimewa.Negara juga mengakui dan menghormati kesatuankesatuan masyarakat hukum adat beserta hak-hak 
tradisionalnya sepanjang masih hidup dan sesuai dengan perkembangan masyarakat dan prinsipprinsip Negara kesatuan .Republik Indonesia sebagaimana yang diamanatkan Pasal 18B yang dalam hal ini mengangkat Kearifan lokal sebagai salah satu cara yang paling tepat.

Kearifan dimulai dari gagasan-gagasan dari individu yang kemudian bertemu dengan gagasan individu lainnya, seterusnya berupa gagasan kolektif. Kearifan lokal ini biasanya dicipta dan dipraktikkan untuk kebaikan komunitas yang menggunakannya. Ada kalanya kearifan lokal itu hanya diketahui dan diamalkan oleh beberapa orang dalam jumlah yang kecil, misalnya desa. Namun ada pula kearifan lokal yang digunakan oleh sekelompok besar masyarakat, misalnya kearifan lokal etnik.

Kearifan lokal ini juga tidak dapat dilepaskan dari kebudayaan masyarakat yang mendukungnya. Kearifan lokal, biasanya mencakup semua unsur kebudayaan manusia, yang mencakup: sistem religi, bahasa, ekonomi, teknologi, pendidikan, organisasi sosial, dan kesenian. Kearifan lokal bermula dari ide atau gagasan, yang kemudian diaplikasikan dalam tahapan praktik, dan penciptaan material kebudayaan. la akan terus berkembang sesuai dengan perkembangan zaman, intensitas pergaulan sosial, dan enkulturasi sosiobudaya. Apalagi dalam dunia yang tidak mengenal batas seperti sekarang ini, kearifan lokal sangat diwarnai oleh wawasan manusia yang memikirkan dan menggunakannya.

Kearifan lokal di peringkat etnik juga bisa bermacam-macam bidang. Misalnya untuk merespons alam sekitar manusia membuat rumah sekalian dengan aspek-aspek spiritual untuk menjaganya. Begitu juga dengan sistem perkawinan, ada yang mendasarkan kepada perkawinan di luar klen (eksogamus), perkawinan untuk kepentingan politik kekuasaan, perkawinan perempuan melamar lelaki atau sebaliknya. Selain itu, kearifan lokal juga tercermina dalam filsafat atau pandangan hidup manusia yang memikirkan dan menggunakannya. Sebagai contoh dalam masyarakat Batak Toba dikenal dengan filsafat dalihan na tolu (DNT), dalam masyarakat Aceh dikenal adat bak petumeuruhom hukom bak syaiah kuala, dalam kebudayaan Minangkabau ada filsafat alam nan takambang menjadi guru, dalam kebudayaan Jawa terdapat filsafat alon-alon waton kelakon dan sederek, dalam masyarakat Sulawesi ada filsafat persaudaraan universal pelagandong, dan lain-lainnya.(Alfian, 1985:23)

Kearifan lokal juga dapat mendukung kepada keberadaan negara bangsa (nation state) tertentu. Bahkan dalam merumuskan sebuah negara bangsa, selalunya diwarnai oleh kearifan-kearifan lokal yang tumbuh dalam masyarakat yang membentuk dan mencita-citakan negara bangsa tersebut. Misalnya Negara Kesatuan Republik Indonesia (NKRI) yang mempunyai dasar negara Pancasila, sebenarnya adalah proses pemikiran para pendiri bangsa ini untuk membuat dasar negara yang diambil dan digali dari nilai-nilai kearifan lokal Nusantara. Kearifan-kearifan lokal ini kemudian dirumuskan menjadi lima sila yang berdasar kepada bentuk "ikatan sosial budaya" biar berbeda-beda tetapi tetap satu (bhinneka tunggal ika).. Von Savigny menyatakan bahwa Hukum merupakan volgeist dari ,jiwa rakyat yang tidak mudah diterjemahkan melalui pembuatan hukum sekalipun (Azyumardi Azra, 2007: 34)

Melalui makalah ini, penulis akan menguraikan beberapa contoh kearifan lokal dalam konteks pembentuka karakter bangsa Indonesia. Kearifan lokal yang dimaksud bisa saja berasal dari kebudayaan etnik, atau pemikiran kebangsaan dari masyarakat Indonesia, dari rentangan masa kemasa. Selanjutnya menjelaskan bagaimana kearifan lokal ini dapat membentuk karakter bangsa Indoensia, yang seperti kita ketahui memiliki ciri-ciri seperti: suka bergotong royong, religius, nasionalis dan menghargai segala perbedaan dalam konteks persatuan dan kesatuan, pekerja keras, tidak bergaya hidup mewah, dan seterusnya, sebagai karakter yang dicita-citakan bersama, dalam rangka membangun negara bangsa Indonesia. Namun sebelumnya alangkah baiknya diuraikan bagaimana terbentuknya dan eksistensi negara kita yang disebut Indonesia tersebut. Berdasarkan uraian tersebut di atas, permasalahan yang diangkat dalam makalah ini adalah : Bagaimana Urgensi kearifan Lokal Membangun Karakrer Bangsa Dalam Rangka Penyelenggaraan Otonomi Daerah.

\section{B. Pembahasan}

\section{Historis dan Pengertian}

Secara harfiah, Indonesia berasal dari bahasa Yunani Kuno, yaitu dari akar kata Indo yang artinya Hindia dan nesos yang artinya pulau-pulau. Jadi Indonesia maksudnya adalah pulau-pulau Hindia (jajahan Belanda). Dalam sejarah ilmu pengetahuan sosial, pencipta awal istilah Indonesia adalah James Richadson Logan Tahun 1850, ketika ia menerbitkan jurnal yang berjudul Journal of the India Archipelago and Eastern Asia, di Pulau Pinang, Malaya. Jurnal ini terbit dari Tahun 1847 sampai 1859. Selain beliau, tercatat juga dalam sejarah, yang 
menggunakan istilah ini adalah seorang Inggris yang bernama Sir William Edward Maxwell Tahun 1897. la adalah seorang ahli hukum, pegawai pamongpraja, sekretaris jendral Straits Settlements, kemudian menjabat sebagai Gubernur Pantai Emas (goudkust). la memakai istilah Indonesia dalam bukunya dengan sebutan The Islands of Indonesia.

Membuat populer istilah Indonesia adalah Adolf Bastian, seorang pakar etnologi yang ternama. Dalam bukunya yang bertajuk Indonesian order die Inseln des Malayeschen Archipels (1884-1849), ia menegaskan arti kepulauan ini. Dalam tulisan ini ia menyatakan bahwa kepulauan Indonesia yang meliputi suatu daerah yang sangat luas, termasuk Madagaskar di Barat sampai Formosa di Timur. Nusantara adalah pusatnya, yang keseluruhannya adalah sebagai satu kesatuan wilayah budaya. Pengertian istilah ini juga digunakan oleh William Marsden (1754-1836), seorang gewestelijk secretaris Bengkulen. Sementara itu, Gubernur Jenderal Jawa di zaman pendudukan Inggris (1811-1816), Sir Stanford Raffles (1781-1826) dalam bukunya yang bertajuk The History of Java, menyebut juga istilah Indonesia, dengan pengertian yang sama. Kesatuan kepulauan. Pada awalnya, istilah Indonesia hanya digunakan sebagai istilah ilmu pengetahuan saja. Namun, ketika pergerakan nasional muncul di sini, nama ini digunakan secara resmi oleh para pemuda Indonesia untuk mengganti istilah Nederlandsch-Indië. Organisasi yang pertama kali memakai istilah Indonesia adalah perhimpunan Indonesia.

Di zaman penjajahan Belanda, oleh tokoh-tokoh nasional, telah dicoba mengganti istilah Nederlandsch-Indië dengan istilah Indonesia-juga Inboorling, Inlander, dan Inheemsche dengan Indonesiër. Namun pemerintah Belanda tetap dengan pendiriannya, dengan alasan yuridis. Namun setelah Undang-undang Dasar Belanda diubah, sejak 20 September 1940, istilah Nederlandsch-Indië diubah menjadi Indonesië.

Selain istilah Indonesia, dikenal pula istilah sejenis yang juga merujuk kepada pengertian Indonesia. Istilah itu adalah Nusantara. Istilah ini awal kali dikemukakan oleh Patih Gadjah Mada, seorang panglima kerajaan Majapahit di abad ke-12, ketika ia mengucapkan Sumpah Palapa. Istilah
Nusantara ini mengandung makna kawasan pulau-pulau yang terletak di antara dua samudera dan dua benua. Berdasarkan sejarah pula, kawasan Nusantara pernah diperintah oleh dua kerajaan besar, yaitu Kerajaan Melayu Sriwijaya, dan Kerajaan Jawa Majapahit.

Indonesia adalah sebuah negara bangsa yang merdeka pada tanggal 17 Agustus 1945. Indonesia sebelumnya adalah kawasankawasan kepulauan yang mempunyai berbagai sistem pemerintahan kerajaan yang berdiri sendiri. Adapun secara kesejarahan, Indonesia melewati masa-masa animisme dan dinamisme hingga ke abad pertama Masehi. Kemudian datanglah kebudayaan Hindu dan Buddha sejak abad pertama hingga kemudian berkembang sampai abad ketiga belas. Islam pula mulai menampakkan pengaruhnya yang begitu luas dalam kebudayaan Indonesia sejak abad ketiga belas. Kemudian bangsabangsa Eropa terutama dimulai dari Portugis, disusul Belanda dan Inggris menjajah kawasan ini sejak kurun abad keenam belas. Yang paling lama menjajah Indonesia adalah Belanda, kurang lebih sekitar tiga setengah abad. Kemudian terjadi pula penjajahan secara singkat oleh Jepang yaitu di Tahun 1942 sampai 1945. Kemudian merdekalah Indonesia, berkat rahmat Tuhan Yang Maha Kuasa disertai dengan perjuangan fisik dan politik oleh para pemimpinnya.

Di masa kemerdekaan pula masalah tak kunjung selesai. Di masa Orde Lama, Indonesia dihadapkan kepada masalah ideologi yang dampaknya adalah berupa pemberontakanpemberontakan dan perebutan kekuasaan. Pada saat ini Belanda pun masih ingin menguasai Indonesia. Dengan berbagai usaha mereka ingin menjajah kembali. Mereka berintegrasi dengan pasukan sekutu yang telah memenangkan perangnya dengan Jepang, Italia, dan Jerman. Namun sekali lagi berkat kuasa Tuhan, Indonesia mampu mempertahankan kemerdekaannya. Bahkan mampu membebaskan Irian Jaya (Papua) dari penjajahn Belanda. Puncak dari berakhirnya era Orde Lama ini adalah masalah komunisme, yang akhirnya menjadikan Soeharto presiden Tahun 1966. Sejak ini dimulailah masa Orde Baru.

Masa Orde Baru awal begitu bagusnya pertumbuhan ekonomi Indonesia. Ada saat ini pembangunan diprioritaskan di bidang ekonomi. Akhirnya memunculkan para konglomerat yang mampu menyumbang 
pembangunan perekonomian. Pemerintah Orde Baru menerapkan sistem rencana Pembangunan Lima Tahun (Repelita) yang melibatkan para pakar ekonomi terutama lulusan Amerika Serikat ("mafia Berkeley"). Akhirnya pemerintahan yang "otoriter" ini, harus menyelesaikan tugasnya selepas 32 tahun berkuasa. Beberapa tahun menjelang runtuhnya Orde Baru ditandai dengan hancurnya sistem perekonomian Indonesia. Akhirnya 1998 muncullah pemerintahan Orde Reformasi, yang menginginkan demokratisasi dibuka.

Masa Reformasi diwarnai oleh semakin demokratisnya sistem politik nasional. Namun ekonomi masih belum pulih di bawah tiga masa pemerintahan presidennya. Namun berbagai perkembangan menarik terjadi, yaitu perdamaian Aceh dengan pemerintah. Begitu juga berkembangnya demokratisasi. Sistem pemerintahan yang langsung ditentukan oleh rakyat membawa secerca harapan. Kini Indonesia telah merdeka lebih dari enam dasawarsa. Demikian sekilas lintasan sejarah bangsa Indonesia.

Pada masa sekarang ini, Indonesia sebagai sebuah negara bangsa merupakn sebuah negara yang sistem pemerintahannya berbentuk republik, dengan sistem yang dianut demokrasi. Landasan ideologinya Pancasila dan landasan konstitusionalnya Undang-undang Dasar 1945. Pemerintahan dan negara langsung dipimpin seorang presiden, dengan sistem kabinet presidensial. Indonesia secara kewilayahan adalah terbentang dari 6 derajat Lintang Utara sampai 11 derajat Lintang Selatan, serta 95 derajat Bujur Timur sampai 145 derajat Bujur Timur. Terbentang dari Sabang sampai Merauke, serta Timor sampai ke Talaud. Indonesia adalah sebagai satu kesatuan ideologi, politik, sosial, ekonomi, pertahanan, dan kemanan nasional. Jumlah penduduk Indonesia sekarang ini adalah sekitar 240 juta jiwa. Agama resmi Islam, Katolik, Protestan, Hindu, Budha, ditambah aliranaliran kepercayaan.

Indonesia kini sedang mengalami masalah-masalah ekonomi, politik dan pertikaian bernuansa agama di dalam negeri, dan beberapa daerah sedang berusaha untuk mendapatkan kemerdekaan, yaitu Aceh dan Papua. Timor Timur mendapatkan kemerdekaan pada tahun 2002 setelah 24 tahun dikuasai Indonesia dan 3 tahun di bawah administrasi PBB. Pada Desember
2004 dan Maret 2005, Aceh dan Nias dilanda dua gempa bumi besar yang totalnya menewaskan ratusan ribu jiwa. (Lihat gempa bumi Samudra Hindia 2004 dan gempa bumi Sumatra Maret 2005.) Kejadian ini disusul oleh gempa bumi di Yogyakarta dan tsunami yang menghantam pantai Pangandaran dan sekitarnya, serta banjir lumpur di Sidoarjo pada 2006 yang tidak kunjung terpecahkan. Penduduk Indonesia dapat dibagi secara garis besar dalam dua kelompok. Di bagian barat Indonesia penduduknya kebanyakan adalah suku Melayu sementara di timur adalah suku Papua, yang mempunyai akar di kepulauan Melanesia. Banyak penduduk Indonesia yang menyatakan dirinya sebagai bagian dari kelompok suku yang lebih spesifik, yang dibagi menurut bahasa dan asal daerah, misalnya Jawa, Sunda, atau Batak. Islam adalah agama mayoritas yang dipeluk oleh sekitar $85,2 \%$ penduduk Indonesia, yang menjadikan Indonesia negara dengan penduduk muslim terbanyak di dunia. Sisanya beragama Protestan $(8,9 \%)$, Katolik (3\%), Hindu $(1,8 \%)$, Buddha $(0,8 \%)$, dan lain-lain $(0,3 \%)$ (Data Statistik: 2013) Kebanyakan penduduk Indonesia bertutur dalam bahasa daerah sebagai bahasa ibu, namun bahasa resmi Indonesia, bahasa Indonesia, diajarkan di seluruh sekolah-sekolah di negara ini dan dikuasai oleh hampir seluruh penduduk Indonesia.

Jenis kesenian di Indonesia banyak dipengaruhi oleh beberapa kebudayaan. Tari Jawa dan Bali yang terkenal, misalnya, berisi aspek-aspek kebudayaan dan mitologi Hindu. Sebuah candi Hindu dari abad ke-10 di Jawa. Banyak juga seni tari yang berisikan nilai-nilai Islam. Beberapa di antaranya dapat ditemukan di daerah Sumatra seperti tari saman,meusukat, dan seudati dari Nanggroe Aceh Darussalam. Selain itu yang cukup terkenal di dunia adalah wayang kulit yang menampilkan kisah-kisah tentang kejadian mitologis.

Seni pantun, gurindam, dan sebagainya dari pelbagai daerah seperti pantun Melayu, dan pantun-pantun lainnya acapkali dipergunakan dalam acara-acara tertentu yaitu perhelatan, pentas seni, dan lain-lain. Di bidang busana, warisan budaya yang terkenal di seluruh dunia adalah kerajinan batik. Beberapa daerah yang terkenal akan industri batik meliputi Yogyakarta, Solo, dan juga Pekalongan. Busana asli Indonesia dari Sabang sampai Merauke lainnya dapat 
dikenali dari ciri-cirinya yang dikenakan di setiap daerah antara lain baju kurung dengan songketnya dari Sumatra Barat (Minangkabau) yang bersamaan khasnya dari teluk belanga seperti dari daerah Melayu, kain ulos dari Sumatra Utara, busana kebaya yang sering dikenakan dari DKI Jakarta (Betawi) dan Jawa Barat (Sunda), busana khas Dayak di Kalimantan, baju bodo dari Sulawesi Selatan, busana berkoteka dari Papua, dan sebagainya. Pencak silat adalah seni bela diri yang unik yang berasal dari wilayah Indonesia. Seni bela diri ini kadangkadang ditampilkan pada acara-acara pertunjukkan yang biasanya diikuti dengan musik tradisional Indonesia berupa gamelan dan seni musik tradisional lainnya sesuai dengan daerah asalnya.

Seni musik di Indonesia, baik tradisional maupun modern sangat banyak terbentang dari Sabang hingga Merauke. Musik tradisional termasuk juga keroncong Jawa dikenali oleh hampir semua rakyat Indonesia, namun yang lebih berkuasa dalam paras lagu di Indonesia yaitu seni lagu modern kemudian dangdut. Genre dangdut ini adalah salah satu musik Indonesia yang sudah merakyat di wilayah Nusantara, yang dipadu dari unsur musik Melayu, India, dan juga musik tradisional Indonesia. Dinamakan dangdut karena suara musik yang terdengar adalah suara dang dan dut dan musik dangdut lebih dikuasai oleh suara gendang tabla dan seruling. Lagu-lagu dangdut biasanya didendangkan oleh pedangdut dengan goyangannya yang seronok dan gagasan yang didukung serta memiliki kemampuan untuk memanfaatkan potensi lingkungan. Sebagaimana dimaksudkan dalam teori gelombang keempat yang digagas oleh Alfin Toffler (Koentjaraningrat, 1985: 25).

Seperti halnya masyarakat Lampung dengan kearifan lokal melalui piil pesenggiri yang berunsurkan (1) nemui nyiman, (2) nengah nyappur, (3) sakai sambaiann dan (4) juluk adok. Nemui nyimah, terdiri dari dua kata yaitu nemui yang berarti tamu dan nyimah yang berasal dari kata simah, yang berarti santun. Unsur ini kita jadikan sebagai unsur yang pertama dan utama, karena merupakan titik tolak eksistensi manusia. Aktivitas pertemuan atau pertamuan adalah mempertemukan dua konsep atau kepentingan yang berbeda, untuk mencari persamaan. Persamaan itu sangat mungkin didapatkan ketika setiap seseorang memeiliki produksi atau penghasilan yang melebihi kebutuhan dirinya dan orang orang yang berada di bawah tanggung jawabnya. core nemui nyimah adalah produktif ( Hilman Hadikusumah, 1985: 58)

Nengah Nyappur, terdiri dari dua kata, yaitu kata nengah dan nyappur, nengah memiliki arti (1) kerja keras, (2) berketerampilan dan (3) pertandingan. Sedang kata nyappur berarti tenggang rasa. Untuk mampu melaksanakan dan menjaga atau kemampuan melaksanakan nemui nyimah seseorang harus kerja keras agar produksi selalu bertambah. Kerja keras itu juga harus memiliki makna tenggang rasa, karena seseorang harus bekerja bukanlah untuk kepentingan pribadi semata, melainkan dapat dinikmati bersama. Untuk mempertahankan itu maka seseorang harus memeiliki karakter dan kemampuan bersaing, kompetitif. Sakai Sambaian, terdiri dari dua kata yaitu kata sakai yang berasal dari akai yang artinya terbuka untuk dibaca, dianalisis dan bahkan di kritisi. Dan kata sambai yang berarti melihat atau meneliti, atau membaca, memelihara dan sebagainya. Setelah dua kata ini digabung maka akan bermakna sebagai siap diberi dan siap memberi, atau dengan kata lain take and give. Kooperatif.

Juluk Adok, terdiri dari dua kata juluk adalah nama yang diberikan ketika seorang anak telah mampu merumuskan cita citanya, kemampuan ini dianggap sebagai perubahan pertama yang paling menentukan masa depannya, kata Adok yaitu nama atau gelar yang diberikan kepada seseorang, ketika seseorang itu telah mencapai apa yang dicitakan. Dengan demikian maka juluk dan adek ini menghendaki akan adanya perubahan atau pembaharuan, inovatif (Hilman Hadikusumah, 1985: 70) Jumlah relatif banyak. Unsur demi unsur dari piil pesenggiri diperkenalkan dan sosialisasikan untuk dipraktekkan dalam kehidupan sehari hari.

Dalam setiap upacara selalu saja pimpinan adat menjadi pengarah bagi komunitas adat, sehingga setiap pimpinan adat menjadi guru bagi komunitas yang bersangkutan. Nilai nilai kearifan tradisional diajarkan oleh pendukung, pelaku dan pelaksanan dari kearifan tradisional itu sendiri. Sehingga komunitas dapat dengan mudahnya diterima serta difahami secara mendalam akan isinya. 
Tetapi peraturan lebih lanjut, ketika Pemerintah mengeluarkan UU tentang Pemerintahan Pedesaan, maka terjadilah pergeseran pengaruh, yang semula kepemimpinan lebih banyak diemban oleh pemangku adat, maka sejak saat itu kepemimpinan dijalankan oleh Kepala Desa yang dipilih. Imbas dari kebijakan ini adalah melemahnya kepemimpinan adat ( Tengku Lah Husni:1986:56) Sebenarnya upaya revitalisasi lembaga adat sebagai antisipasi dari melemahnya kepemimpinan adat, telah tercantum dalam Renstra Dinas Pendidikan Provinsi Lampung tahun 2001 - 2006, tetapi ternyata program itu tidak berjalan secara maksimal.

Kini para pimpinan adat nyaris kehilangan popularitasnya, mereka nyaris tak dikenal. Popularitas itu redup bersamaan dengan kurangnya peran yang dimainkan oleh pimpinan adat. Pimpinan adat sering hanya diperankan dalam upacara perhelatan perkawinan, yaitu sekitar acara pelamaran serta beberapa upacara seremonial lainnya. Dan ini memang masih tetap dipertahankan terutama oleh mereka mereka yang memiliki kekuatan ekonomi yang memadai, karena upacara yang berbau adat membutuhkan biaya yang relatif tinggi.

Untuk mempertahankan kearifan lokal budaya daerah Lampung, maka Pemerintah daerah memiliki tanggung jawab yang besar, bukan hanya sekedar mempersiapkan bantuan finansial, tetapi juga merumuskan langkah langkah teknis yang akan ditempuh. Bukan mengambil alih peran lembaga adat, tetapi justeru harus melakukan revitalisasi lembaga adat yang hingga sekarang masih eksis dari berbagai suku yang ada di nusantara, masyarakat hukum adat yang ada di Provinsi lampung sejak awal berdirinya Provinsi sudah memiliki keanekaragaman suku, sejak adanya program transmigrasi pemerintah dan lokal, sehingga tidak berlebihan kalau Provinsi lampung disebut dengan Indonesia mini yang selalu siap membangun dalam penyelenggaraan otonomi daerah bersama kekerabatan masyarakat hukum adat.

Program revitalisasi lembaga adat bukan berarti memutar balik jarum jam, tetapi karena lembaga adat memiliki kelebihan ikatan dibanding ikatan ikatan yang lain, yaitu ikatan kekeluargaan, karena perkawinan dan lain sebagainya. Apalagi kini banyak sekali desa desa sebagai konsentrasi komunitas adat banyak yang tinggal di daerah yang mengalami kelambatan dalam sentuhan pembangunan. Banyak sekali kampung kampung tua yang justeru baru disentuh pembangunan setelah era reformasi. Di Lampung umpamanya muncul program "Tiyuh Toho" untuk membangun desa desa tua yang benar benar tertinggal, karena minus fasilitas layanan umum, seperti sekolah, Puskesmas, dan lain sebagainya.

Mengharapkan kehadiran lembaga adat yang memiliki kemampuan untuk memberdayakan perekonomian komunitas adatnya. Pergeseran peradaban juga menggeser aktivitas agraris yang semula menjadi andalan, guna memasuki era industrialisasi dan bahkan era komunikasi. Bahkan sekarang sebenarnya telah memasuki era keempat, Yang mengandalkan kemampuan untuk menyusun konsep berdasarkan nilai nilai budaya serta potensi lingkungan. Dan selanjutnya perkembangan nilai budaya milik lembaga adat berada di tangan para intelektual dari kelompok adat yang ada. Memang akan sulit dan bahkan mustahil pihak luar akan memiliki kemampuan melakukan interfensi ke dalam lembaga adat. Walau membentuk lembaga adat buatan sekalipun.(Tengku Lah Husni, 1985:61)

Negara akan memiliki peluang menanamkan nilai nilai budaya milik komunitas beserta lembaga adat melalui dunia pendidikan baik, formal maupun nonformal. Manfaatnya adalah menanamkan kemampuan untuk mengapresiasi nilai nilai tersebut kepada publik melalui peserta didik ataupun pelatihan. harus melakukan pembenahan dalam dunia pendidikan, piil pesenggiri tidak cukup diajarkan dengan pendekatan akademis belaka, tetapi harus diciptakan model pembelajarannya, metode dan teknologi pembelajarannya serta media belajar. Nilai nilai ini akan diapresiasi berdasarkan banyaknya pengalaman belajar, pengalaman belajar didapatkan dari tingginya kesempatan bersentuhan dengan media pembelajaran.

\section{2. dasar Hukum Kebudayaan Nasional Indonesia}

Sebagai sebuah negara bangsa, Indonesia telah meletakkan dasar konstitusionalnya mengenai kebudayaan nasional, seperti yang termaktub dalam Pasal $18 \mathrm{~B}$ dan Pasal 32 Undang-undang Dasar 1945. Bahkan lambang negara Indonesia, Garuda Pancasila merentangkan tulisan Bhinneka Tunggal Ika 
(yang artinya biar berbeda-beda tetapi tetap satu). Selengkapnya Pasal 32 ayat (1) dan (2) berbunyi sebagai berikut.

(1) Negara memajukan kebudayaan nasional Indonesia di tengah peradaban dunia dengan menjamin kebebasan masyarakat dalam memelihara dan mengembangkan nilai-nilai budayanya.

(2) Negara menghormati dan memelihara bahasa daerah sebagai kekayaan budaya nasional

Pasal 32 UUD 1945 yang diamandemen pada kali yang keempat tersebut di atas, pada Pasal (1) memberikan arahan bahwa negara memajukan kebudayaan nasional Indonesia di tengah peradaban dunia, dengan menjamin kebebasan masyarakat dalam memelihara dan mengem-bangkan nilai-nilai budayanya. Artinya bangsa Indonesia sadar bahwa budaya nasional mereka berada di dalam arus globalisasi, namun untuk mempertahankan jati diri masyarakat diberi kebebasan dan bahkan sangat perlu memelihara dan mengembangkan nilai-nilai budaya (tradisi atau etniknya). Pada Pasal (2) pula, negara menghormati dan memelihara bahasa daerah sebagai kekayaan budaya nasional. Dengan demikian jelas bagi kita bahwa bahasa daerah (dan juga kesenian atau budaya daerah/etnik) sebagai bahagian penting dari kebudayaan nasional. Artinya kebudayaan nasional dibentuk oleh kebudayaan (bahasa) etnik atau daerah-bukan kebudayaan asing. Dengan demikian jelas bahwa Indonesia memiliki budaya nasional, yang berasal dari budaya etnik, bukan penjumlahan budaya etnik.

Beberapa dasawarsa menjelang terbentuknya Negara Kesatuan Republik Indonesia, para intelektual dan aktivis budaya kita telah memiliki gagasan tentang kebudayaan nasional. Dalam konteks ini, mereka mengajukan pemikirannya masingmasing sambil berpolemik apa itu kebudayaan nasional dan ke mana arah tujuannya. Pelbagai tulisan membahas gagasan itu dari berbagai sudut pandang, yang terbit dalam kurun masa dekade 1930-an.

Sebahagian tulisan ini merupakan hasil dari Permusyawaratan Perguruan Indonesia di Surakarta (Solo), pada 8 sampai 10 Juni 1935. Di antara intelektual budaya yang mengemukakan gagasannya adalah: Sutan Takdir Alisyahbana (STA) pengarang dan juga mahasiswa Sekolah
Tinggi Hukum (rechtshogeschool) di Jakarta; Sanusi Pane, seorang pengarang; Soetomo, dokter dan pengarang; Tjindarbumi, wartawan; Poerbatjaraka, pakar filologi; Ki Hajar Dewantara, pendiri dan pemimpin perguruan nasional Taman Siswa (Koentjaraningrat,1985:78)

Gagasan-gagasan mereka secara garis besar adalah sebagai berikut. Sutan Takdir Alisyahbana yang berasal dari Sumatera, berpendirian bahwa gagasan kebudayaan nasional Indonesia, yang dalam artikelnya diistilahkan dengan Kebudayaan Indonesia raya, sebenarnya baru mulai muncul dan disadari pada awal abad kedua puluh, oleh generasi muda Indonesia yang berjiwa dan bersemangat keindonesiaan. Menurutnya, sebelum gagasan Indonesia Raya disadari dan dikembangkan, yang ada hanyalah kebudayaan-kebudayaan suku bangsa di daerah. STA menganjurkan agar generasi muda Indonesia tidak terlalu tersangkut dalam kebudayaan pra-Indonesia, dan dapat membebaskan diri dari kebudayaan etniknya-agar tidak berjiwa provinsialis, tetapi dengan semangat Indonesia baru. Kebudayaan Nasional Indonesia merupakan satu kebudayaan yang dikreasikan, yang baru sama sekali, dengan mengambil banyak unsur dari kebudayaan yang kini dianggap paling universal, yaitu budaya Barat. Unsur yang diambil terutama dalam 4 bidang yaitu teknologi, orientasi ekonomi, organisasi, dan sains (ilmu pengetahuan). Orang Indonesia harus mempertajam rasio akalnya dan mengambil dinamika budaya Barat. Pandangan ini mendapat sanggahan sengit dari beberapa pemikir lainnya.

Sanusi Pane yang juga berasal dari Sumatera, menyatakan bahwa kebudayaan nasional Indonesia sebagai kebudayaan Timur, harus mementingkan aspek kerohanian, perasaan, dan gotong-royong, yang bertentangan dengan kebudayaan Barat yang sangat berorientasi kepada materi, intelektualisme, dan individualisme. Sanusi Pane tidak begitu setuju dengan STA yang dianggapnya dalam menggagas kebudayaan nasional Indonesia terlalu berorientasi kepada kebudayaan Barat dan harus membebaskan diri dari kebudayaan pra-Indonesia. Karana itu berarti pemutusan diri dari kesinambungan sejarah budaya dalam rangka memasuki zaman Indonesia baru.

Poerbatjaraka menganjurkan agar orang Indonesia banyak mempelajari sejarah 
kebudayaannya, agar dapat membangun kebudayaan yang baru. Kebudayaan Indonesia baru itu harus berakar kepada kebudayaan Indonesia sendiri atau kebudayaan pra-Indonesia.

Ki Hajar Dewantara menyatakan bahwa kebudayaan nasional Indonesia adalah puncak-puncak kebudayaan daerah. Soetomo menganjurkan pula agar dasar-dasar sistem pendidikan pesantren dipergunakan sebagai dasar pembangunan pendidikan nasional Indonesia, yang ditentang oleh STA. Sementara itu, Adinegoro mengajukan sebuah gagasan yang lebih moderat, yaitu agar pendidikan nasional Indonesia didasarkan pada kebudayaan nasional Indonesia, sedangkan kebudaya-annya harus memiliki inti dan pokok yang bersifat kultur nasional Indonesia, tetapi dengan kulit (peradaban) yang bersifat kebudayaan Barat.

Sebuah gagasan akan dilanjutkan ke dalam praktik, agar fungsional dalam masyarakat pendukungnya. Fungsi sebuah gagasan bisa saja relatif sedikit, namun boleh pula menjadi banyak. Demikian pula gagasan kebudayaan nasional memiliki berbagai fungsi dalam negara Indonesia merdeka. Koentjaraningrat (1995) seorang ilmuwan antropologi kenamaan Indonesia, menyebutkan bahwa kebudayaan nasional Indonesia memiliki dua fungsi, yaitu: (i) sebagai suatu sistem gagasan dan pralambang yang memberi identitas kepada warga negara Indonesia dan (ii) sebagai suatu sistem gagasan dan pralambang yang dapat dipergunakan oleh semua warga negara Indonesia yang bhinneka itu, untuk saling berkomunikasi, sehingga memperkuat solidaritas. Dalam fungsinya yang pertama, kebudayaan nasional Indonesia memiliki tiga syarat: (1) harus merupakan hasil karya warga negara Indonesia, atau hasil karya orang-orang zaman dahulu yang berasal dari daerah-daerah yang sekarang merupakan wilayah negara Indonesia; (2) unsur itu harus merupakan hasil karya warga negara Indonesia yang tema pikirannya atau wujudnya mengandung ciri-ciri khas Indonesia; dan (3) harus sebagai hasil karya warga negara Indonesia lainnya yang dapat menjadi kebanggaan mereka semua, sehingga mereka mau mengidentitaskan diri dengan kebudayaan tersebut( Koentjaraningrat,1985:96).

Dalam fungsi kedua, harus ada tiga syarat yaitu dua di antaranya sama dengan syarat nomor satu dan dua fungsi pertama, syarat nomor tiga yaitu harus sebagai hasil karya dan tingkah laku warga negara Indonesia yang dapat dipahami oleh sebahagian besar orang Indonesia yang berasal dari kebudayaan suku-suku bangsa, umat agama, dan ciri keturunan ras yang aneka warna, sehingga menjadi gagasan kolektif dan unsurunsurnya dapat berfungsi sebagai wahana komunikasi dan sarana untuk menumbuhkan saling pengertian di antara aneka warna orang Indonesia, dan mempertingi solidaritas bangsa.

Menurut penulis, dalam proses pembentukan budaya nasional Indonesia, selain orientasi dan fungsinya, juga harus diperhatikan keseimbangan etnisitas, keadilan, dan kejujuran dalam mengangkatnya dari lokasi daerah (etnik) ke tingkat nasional. Sebaiknya proses ini terjadi secara wajar, alamiah dan natural, dan bukan bersifat pemaksaan pusat terhadap daerah atau sebaliknya. Di samping itu proses itu harus pula menyeimbangkan antara bhinneka dan ikanya budaya Indonesia. Perlu disadari pula bahwa budaya nasional bukan penjumlahan kuantitatif budaya etnik Indonesia. Budaya nasional terjadi sebagai proses dialogis antara budaya etnik dan setiap etnik merasa memilikinya ( sance of bilonging ).

Budaya nasional kita yang dapat kita rasakan wujudnya adalah bahasa Indonesia. Kemudian pakaian dalam bentuk peci, batik, jas, kebaya, baju kurung juga menjadi pakaian nasional. Kesenian seperti keroncong, tari serampang dua belas, tari poco-poco, dangdut, dapat pula kita kategorikan sebagai kesenian nasional Indonesia. Sistem pertanian subak di Bali, budaya kegotongroyongan, sikap peramah, pemaaf, suka mengolah secara kreatif budaya seluruh dunia, adalah beberapa hal yang mendukung kebudayaan nasional.

Budaya nasional ini menjadi jati diri tersendiri bagi bangsa Indonesia. Budaya nasional dibentuk dan didukung terutama oleh budaya etnik atau daerah. Untuk itu diperlukan pemeliharaan dan pengembangan warisan budaya etnik atau tradisi Indonesia dari satu generasi ke generasi berikutnya. Agar kita memiliki jati diri yang kokoh seacara etnik dan nasional maupun transnasional. Caranya ialah seperti kata pepatah tak kenal maka tak sayang. Oleh karena itu, perlu dilakukan pagelaran seni pertunjukuan, pameran seni rupa, penayangan budaya 
etnik dalam media massa seperti televisi, koran, video, internet, dan media-media lainnya. Selain itu, setiap etnik di Indonesia juga jangan hanya mengapresiasi kesenian etniknya sendiri. Mereka harus mampu menjadi pengamat outsider bagi keseniankesenian etnik lain. Kesadaran kultural tentang keberanekaragaman adalah anugerah dan kekayaan dari Tuhan dan perlu terus menerus ditumbuhkembangkan, bukan saling menghina dan mengejek. Agama, budaya, dan konsep ketatanegaraan kita juga menganjurkan tentang pentingnya menghargai perbedaan kultural ini, seperti yang akan diuraikan berikut ini.

\section{Kearifan Lokal dalam Konteks Pembentukan Karakter Bangsa}

Setelah diuraikan secara panjang lebar tentang eksistensi Indonesia sebagai bangsa dan kebudayaan nasionalnya, maka berikut ini akan dicari dan dikaji bagaimana kearifankearifan lokal yang ada di Indonesia dalam konteks pembentukan karakter bangsa. Kearifan-kearifan lokal di Indoensia ini sangat kaya, beragam, dan menyebar di keseluruhan kawasan di Indonesia. Kearifan lokal ini umumnya dapat dijumpai dalam adat. Istilah inilah yang menjadi dasar dari kearifan lokal bangsa Indonesia. Adat dijumpai dalam kebudayaan etnik di seluruh Indonesia. Adat masyarakat Nusantara ini, memiliki konsepkonsepnya sendiri pula. Di Aceh adatnya disebut dengan adat bak petumeuruhom hukom bak syiah kuala. Dalam kebudayaan Minangkabau adat dikonsepkan sebagai adat basandikan syarak, syarak basandikan kitabullah, syarak mangato, adat mamakai. Berikut dideskripsikan konsep kearifan lokal (adat) Melayu.

Menurut Lah Husni adat pada etnik Melayu tercakup dalam empat ragam, iaitu: (1) adat yang sebenar adat; (2) adat yang diadatkan; (3) adat yang teradat, dan (4) adat istiadat.

(1) Adat yang sebenar adat adalah apabila menurut waktu dan keadaan, jika dikurangi akan merusak, jika dilebihi akan mubazir (sia-sia).

Proses ini berdasar kepada: (a) hati nurani manusia budiman, yang tercermin dalam ajaran adat: pisang emas bawa belayar; Masak sebiji di dalam peti; Hutang emas dapat dibayar; Hutang budi dibawa mati. (b) kebenaran yang sungguh ikhlas, dengan berdasar pada: berbuat karena Allah bukan karena ulah; (c) keputusan yang berpadan, dengan berdasar kepada: hidup sandarmenyandar, pisang seikat digulai sebelanga, dimakan bersama-sama. yang benar itu harus dibenarkan, yang salah disalahkan. Adat murai berkicau, tak mungkin menguak. Adat lembu menguak, tak mungkin berkicau. Adat sebenar adat ini menurut konsep etnosains Melayu adalah: penuh tidak melimpah, berisi tidak kurang, yang besar dibesarkan, yang tua dihormati, yang kecil disayangi, yang sakit diobati, yang bodoh diajari, yang benar diberi hak, yang kuat tidak melanda, yang tinggi tidak menghimpit, yang pintar tidak menipu, hidup berpatutan, makan berpadanan. Jadi ringkasnya, hidup itu seharusnya harmonis, baik mencakup diri sendiri, seluruh negara, dan lingkungan hidupnya. Tidak ada hidup yang bernafsi-nafsi. Inilah adat yang tidak boleh berubah( Tengku Lah Husni, 1986:57)

(2) Adat yang diadatkan adalah adat itu bekerja pada suatu landasan tertentu, menurut mufakat dari penduduk daerah tersebut-kemudian pelaksanaannya diserahkan oleh rakyat kepada yang dipercayai mereka.

Sebagai pemangku adat adalah seorang raja atau penghulu. Pelaksanaan adat ini wujudnya adalah untuk kebahagiaan penduduk, baik lahir ataupun batin, dunia dan akhirat, pada saat itu dan saat yang akan datang. Tiap-tiap negeri itu mempunyai situasi yang berbeda dengan negeri-negeri lainnya, lain lubuk lain ikannya lain padang lain belalangnya. Perbedaan keadaan, tempat, dan kemajuan sesuatu negeri itu membawa resam dan adatnya sendiri, yang sesuai dengan kehendak rakyatnya, yang diwarisi dari leluhurnya. Perbedaan itu hanyalah dalam lahirnya saja, tidak dalam hakikinya. Adat yang diadatkan ini adalah sesuatu yang telah diterima untuk menjadi kebiasaan atau peraturan yang diperbuat bersama atas mufakat menurut ukuran yang patut dan benar, yang dapat dimodifikasi 
sedemikian rupa secara fleksibel. Dasar dari adat yang diadatkan ini adalah: penuh tidak melimpah, berisi tidak kurang, terapung tidak hanyut, terendam tidak basah (Tengku Lah Husni,1986:61)

(3) Adat yang teradat adalah kebiasaankebiasaan yang secara berangsurangsur atau cepat menjadi adat.

Sesuai dengan pepatah: sekali air bah, sekali tepian berpindah, sekali zaman beredar, sekali adat berkisar. walau terjadi perubahan adat itu, inti adat tidak akan lenyap: adat pasang turun-naik, adat api panas, dalam gerak berseimbangan, di antara akhlak dan pengetahuan. Perubahan itu hanya terjadi dalam bentuk ragam, bukan dalam hakiki dan tujuan semula. Umpamanya jika dahulu orang memakai tengkuluk atau ikat kepala dalam suatu majelis, kemudian sekarang memakai kopiah itu menjadi pakaian yang teradat. Jika dahulu berjalan berkeris atau disertai pengiring, sekarang tidak lagi. Jika dahulu warna kuning hanya raja yang boleh memakainya, sekarang siapa pun boleh memakainya.

(4) Adat istiadat adalah kumpulan dari berbagai kebiasaan, yang lebih banyak diartikan tertuju kepada upacara khusus seperti adat: perkawinan, penobatan raja, dan pemakaman raja. Jika hanya adat saja maka kecenderungan pengertiannya adalah sebagai himpunan hukum, misalnya: hukum ulayat, hak asasi dan sbagainya. Dalam konteks kebudayaan Melayu, adat istiadat ini mencakup daur hidup manusia Melayu, yang tercermin dalam upacara melenggang perut saat perempuan Melayu hamil. Kemudian upacara kelahiran, akikah, manabalkan nama, bercukur, dan memijak tanah. Seterusnya upacara khitanan pada saat akil baligh. Kemudian ada pula upacara perkawinan adat Melayu, yang mencakup tahapan-tahapan seperti merisik kecil, meminang, jamu sukut, akad nikah, hempang pintu, hempang batang, hempang kipas, duduk di pelaminan, mandi bedimbar, meminjam pengantin, dan setersnya. Selanjutnya ada pula upacara kematian, membaca Yassin, kirim doa, dan seterusnya. Dalam kebudayaan Melayu terdapat juga upacara-upacara yang bersifat menyatu dengan alam (kosmologi) seperti mulaka nukah, mulaka ngerbah, jamu laut, mandi Syafar, dan lain-lainnya. Yang jelas adat istiadat Melayu lahir karena respons terhadap alam.(Tengku Lah Husni,1986:62)

Dalam adat Melayu kearifan-kearifan lokal dalam konteks membentuk kepribadian dan kebangsaan, sangat lekat dengan konsep adat yang diadatkan. Bahwa orang Melayu sangatlah menghargai pemimpin seperti sultan, raja, perdana menteri, menteri, panglima, penghulu, ketua mukim, dan lain-lainnya. Orang Melayu perlu memiliki pemimpin yang adil, bijaksana, bisa diperaya (amanah), selalu berusaha untuk benar dalam hidup, dan lain-lainnya. Pemimpin menjadi sebuah kewajiban dalam tata pemerintahan dan politik dalam kebudayaan Melayu. Seperti tercermin dalam ajaran adat: Apa tanda Melayu jati/ mengangkat pemimpin bijak bestari/ Apa tanda Melayu jati/ Pemimpin dan ulama mesti bersebati. Dengan adanya pemimpin dan rakyat yang dipimpin menjadikan umat Melayu memiliki tata pemerintahnya dan selanjutnya ketika nasionalisme muncul mereka membentuk negara bangsa. Ini salah satu karakter kepemimpinan yang bisa diterapkan dalam konteks menuju karakter bangsa.

Dalam adat Melayu juga dikenal kearifan lokal, bahwa hidup dikandung adat, biar mati anak asal jangan mati adat. Artinya bahwa orang Melayu sangatlah memperhatikan kesinambungan dan pendidikkan kebudayaan. Bila adat itu lestari maka akan lestarilah kebudayaan Melayu. Jika keturunan kita berbuat salah maka kita jangan segan memberikan hukuman atau sangsi sosial sebagaimana yang berlaku.

Bukan saja kearifan lokal Melayu, beberapa kelompok etnik di Nusantara ini juga memiliki kearifan lokal yang berkaitan dengan pembentukan karakter bangsa. Misalnya pada etnik Nias, sistem penggolongan derajat manusia berasaskan tingkat-tingkat kehidupan, dimulai dari janin sampai kehidupan akhirat. Pengertian bosi ini mencakup dua belas tingkat kehidupan. Dalam konteks ini, bosi nantinya mengarahkan manusia untuk berusaha mencapai tingkat tertinggi, agar setelah ia mati, akan memperoleh kebahagiaan di dalam teteholi ana'a (sorga). Adapun 
pembagian bosi itu adalah: fangaruwusi (memperlihatkan kandungan); tumbu (lahir); famatoro doi (memberi nama); famoto (sirkumsisi); falowa (kawin); famadadao omo (membangun rumah); fa'aniha banua (memasuki persekutuan desa); famaoli (menjadi anggota adat); fangai toi (mengambil gelar); fa'amokho (kekayaan); mame'e go banua (menjamu orang se desa) dan mame'e go nori (menjamu orang satu ori, beberapa desa (Muhammad Takari dan Heristina Dewi,2008:87:. Inti dari kearifan lokal itu adalah, bahwa sebagai sebuah suku dan juga bangsa setiap orang Nias selalu berinteraksi dan menjadi bahagian komunitas sosial. Dalam hal ini seorang pemimpin sosial mestilah mampu memberikan rezekinya kepada orang lain. Seorang pemimpin adalah tangan di atas bukan di bawah.

Selain itu kearifan lokal dalam konteks pembangunan karakter bangsa juga terdapat dalam kebudayaan Batak Toba. Sebagai satu kesatuan etnik, orang-orang Batak Toba mendiami suatu daerah kebudayaan (culture area) yang disebut dengan Batak Toba. Mereka disebut orang Toba. Menurut vergouwen, masyarakat Batak Toba mengenal beberapa kesatuan tempat yaitu: (1) kampung, lapangan empat persegi dengan halaman yang bagus dan kosong di tengah-tengahnya, (2) huta, "republik" kecil yang diperintah seorang raja, (3) onan, daerah pasar, sebagai satu kesatuan ekonomi, (4) homban (mata air), (5) huta parserahan, kampung induk dan lain-lain (vergouven J.C,1964:141). Pada dasarnya masyarakat hukum adat batak diperintah oleh seorang Raja huta berdasarkan asas dalihan natolu yang merangkap sebagai tokoh adat. Inti ajaran kearifan lokal seperti terurai di atas adalah bahwa manusia hidup sebagai makhluk sosial yang saling mendukung, demikian yang terjadi di berbagai daerah, hampir seluruh wilayah Indonesia dari Sabang sampai Merauke, memiliki kearifan lokal yang dapat membangun karakter bangsa untuk membangun daerah dalam rangka penyelenggaraan otonomi daerah, berdasarkan prinsip negara kesatuan sebagai integritas bangsa yang patut di jaga kelestariannya dan merupakan kekayaan bangsa Indonesia yang tidak dimiliki oleh negara lain, dan merupakan ciri khas bangsa yang patut di banggakan.

\section{Penutup}

\section{Kesimpulan}

a. Berdasarkan contoh-contoh di atas menggambar dengan jelas bahwa kearifan lokal masyarakat Nusantara terkodifikasi dalam adat. Adat masyarakat Nusantara ini memiliki konsep-konsepnya tersendiri di setiap kelompok etnik. Dalam kearifan lokal Nusantara terdapat nilainilai untuk membentuk karakter bangsa. Nilai-nilai tersebut mencakup: sistem kepemimpinan, hubungan sosial, hidup secara berkelompok, pentingnya berbagi materi dan pengalaman kepada orang lain, belajar terus dari alam, nilai-nilai gotong royong, bagaimana menghadapi perubahan dan globalisasi, sadar akan makhluk yang mulai dari kecil, dewasa, sampai meninggal, hidup tidak boleh sombong, dan seterusnya.

b. Sebagai sebuah bangsa yakni bangsa Indonesia berkarakter positif yang dapat digali nilai karakter berbangsa itu dari kearifan lokal (etnik). Di antara karakter bangsa itu adalah: bersama secara sosial dan bergotong royong, menerapkan nilainilai kebenaran berdasarkan agama dan adat, memiliki pemimpin, menghormati pemimpin, bertindak secara benar, amanah, menjaga persatuan, tidak menghujat, dan seterusnya. Hal inilah yang dilakukaan oleh masing-masing daerah sebagai upaya membangun karakter bangsa di seluruh nusantara untuk memajukan daerah

\section{Saran.}

Pemerintah hendaknya membuat pemetaan terhadap jumlah keseluruhan etnis dan budaya di Indonesia melalui Provinsi masing-masing, untuk selanjutnya memberdayakan tokoh adat dan kekerabatannya untuk berpartisipasi dalam mengambil keputusan dengan bergandeng dengan DPRD dalam rangka pelaksanaan otonomi daerah yang dituangkan dalam peraturan daerah sebagai dasar hukum kebijakan yang dibuat oleh kepala daerah bersama-sama dengan DPRD, sehingga keberadaan masyarakat hukum adat jelas sebagai partisipan pelaksanaan pembangunan di daerah, baik Provinsi maupan Kabupaten/kota. 


\section{daftar Pustaka}

Alfian (ed.), 1985. persepsi Masyarakat tentang Kebudayaan. Jakarta: Gramedia.

Azyumardi Azra, 2007. Islam in the Indonesian World: An Account of Institutional Formation. Bandung: Mizan.

Azyumardi Azra, 2007. Merawat Kemajemukan Merawat Indonesia. Jakarta: Kanisius.

Batara Sangti, 1977. Sejarah Batak. Balige: Karl Sianipar.

Crawfurd, J. 1820. History of the Indian Archipelago. Edinurg: Archibald Constable and Co.

Kamus Besar bahasa Indonesia (versi elektronik), 2010.

Kincaid, D.L. \& W. Schramm, 1978. Asas-asas Komunikasi antara Manusia. (Terjemhan Ronny Adhikarya, Wan Firuz Wan Mustafa, dan Habsah Ibrahim). Pulau Pinang: Penerbit Universiti Sains Malaysia.

Koentjaraningrat, 1980. Sejarah Teori Antropologi I. Jakarta: Rineka Cistra.

Koentjaraningrat, 1985. "Konsep kebudayaan Nasional" dalam persepsi Masyarakat tentang Kebudayaan. Alfian (ed.). Jakarta: Gamedia.

Koentjaraningrat, 1990. pengantar IImu Antropologi. Jakarta: Rineka Cipta.

Tengku Lah Husni, 1986. Butir-butir Adat Budaya Melayu pesisir Sumatera Timur. Jakarta: Departemen Pendidikan dan Kebudayaan.

Leo Suryadinata, 1999. Etnis Tionghoa dan pembangunan Bangsa. Jakarta: Pustaka LP3ES.

Malinowski, 1987. "Teori fungsional dan struktural, " dalam teori artopologi I. Koentjaraningrat (ed.) , Jakarta: Universitas Indonesia Press.

Merriam, Alan P., 1964. The Anthropology of Music. Chicago: Nortwestern University.

Muhammad Takari dan Heristina Dewi, 2008. Budaya Musik dan Tari Melayu Sumatera Utara. Medan: Universitas Sumatera Utara Press.

Muhammad Takari, 2009. "Kebudayaan Nasional Indonesia dan Malaysia: Gagasan, Terapan, dan Bandingannya." dalam Setengah Abad Hubungan Malaysia_Indonesia. (ed. Mohammad Redzuan Othman dkk.) Kuala Lumpur: Arah Publications, pp. 439-472.

Onong U. Effendy, 1988. IImu Komunikasi Teori dan praktek. Bandung: Remadja Rosdakarya.

Radcliffe-Brown, A.R., 1952., Structure and Function in primitive Society. Glencoe: Free Press.

Raffles, Sir Thomas Stanford, 1830. The History of Java. (volume Satu). London: Muray.

Syed Ameer Ali, 1002. Sejarah Evolusi dan Keunggulan Islam. Kuala Lumpur: Dewan Bahasa dan Pustaka, Kementerian Pendidikan Malaysia.

vergouwen, J.C., 1964. The Social Organization and customary Law of the Toba Batak. The Hague: Martinus Nijhoff. 